Pengembangan Rekayasa dan Teknologi, Vol 15, No. 2, Desember 2019, pp 71-75

p-ISSN: 1410-9840 \& e-ISSN: 2580-8850

http://journals.usm.ac.id/index.php/jprt/index

\title{
TERMINAL BARANG SEBAGAI SISTEM PENDATAAN BARANG DI KOPERASI SMP NEGERI 23 SEMARANG BERBASIS WEB
}

\author{
Saifur Rohman Cholil ${ }^{1}$, Amelia Widya Octa Kuncoro Putri ${ }^{2}$ \\ Jurusan Sistem Informasi, Fakultas Teknologi Informasi dan Komunikasi, Universitas Semarang \\ e-mail: cholil@usm.ac.id ${ }^{1}$, Ameliawidya007@gmail.com ${ }^{2}$
}

\begin{abstract}
Abstrak
Sistem komputerisasi saat ini telah umum digunakan termasuk koperasi sekolah, namun tidak semua koperasi sekolah memaksimalkan penggunaan sistem komputer. Kegiatan administrasi dan pendataan masih dilakukan secara manual, dengan mencatat segala kegiatan kedalam buku sesuai dengan kegiatan yang dilakukan. Berkembangnya teknologi informasi pada saat ini, efisiensi dengan mudah dapat diterapkan menggunakan implementasi teknologi informasi. Harapan dari implementasi teknologi informasi ini adalah pengelolaan data barang koperasi tidak dilakukan secara manual. Pembuatan sistem pendataan barang koperasi akan mempermudah, mempercepat staf koperasi dalam melakukan penginputan data barang, pencarian barang dan transaksi penjualan maupun pembelian. Sehingga harapan tersebut dapat dicapai dengan bantuan sistem pendataan barang koperasi. Metode yang digunakan dalam membangun sistem pendataan barang koperasi adalah metode prototyping, dimana nantinya sistem ini dapat dikembangkan lagi. Sistem pendataan barang koperasi dibangun dengan bahasa pemrograman PHP dan database yang digunakan adalah MySQL, sedangkan dalam penggambaran sistem secara umum menggunakan Unified Modeling Language. Fasilitas yang terdapat didalam sistem ini adalah proses transaksi pembelian, proses transaksi penjualan, kelola barang, kelola supplier, cetak laporan penjualan, cetak laporan pembelian, cetak laporan profit dan kelola pengguna. Selain bertujuan untuk mempermudah staf koperasi dalam melakukan pengelolaan data barang koperasi, namun juga memberikan nilai tambah administrasi SMP Negeri 23 Semarang dalam penerapan paperless office.
\end{abstract}

Kata kunci: Terminal Barang, Sistem Pendataan, Web Application

\begin{abstract}
Computerized systems are now commonly used including school cooperatives, but not all school cooperatives maximize the use of computer systems. Administrative activities and data collection are still done manually, by recording all activities into the book according to the activities carried out. The development of information technology at this time, efficiency can easily be applied using the implementation of information technology. The expectation of this information technology implementation is that cooperative data management is not done manually. Making a cooperative data collection system will simplify, accelerate cooperative staff in inputting goods data, search goods and sales and purchase transactions. So that hope can be achieved with the help of cooperative data collection system. The method used in building a cooperative data collection system is the prototyping method, where later this system can be developed again. Cooperative goods data collection system is built with the PHP programming language and database used is MySQL, while in system depiction, in general, using the Unified Modeling Language. The facilities contained in this system are the process of purchasing transactions, sales transaction processes, managing goods, managing suppliers, printing sales reports, printing purchase reports, printing profit reports and managing users. Besides aiming to facilitate cooperative staff in managing cooperative goods data, it also provides added value for the administration of Semarang State Junior High School 23 in the implementation of the paperless office.
\end{abstract}

Keywords: Terminal Barang, Data Collection System, Web Application 
Pengembangan Rekayasa dan Teknologi, Vol 15, No. 2, Desember 2019, pp 71-75

p-ISSN: $1410-9840$ \& e-ISSN: 2580-8850

http://journals.usm.ac.id/index.php/jprt/index

\section{PENDAHULUAN}

Sistem komputerisasi saat ini telah umum digunakan di seluruh bidang termasuk koperasi sekolah. Koperasi sekolah saat ini telah menerapkan sistem komputer dalam pengelolaan administrasi dan sebagainya. Namun tidak semua koperasi memaksimalkan penggunaan sistem komputer. Meskipun menggunakan komputer dalam melakukan kegiatan administrasi dan pendataan, akan tetapi hal tersebut masih dilakukan dengan program-program standar yang ada pada komputer. Hal ini hanya membantu dalam proses input dan menyimpan data, akan tetapi untuk proses output akan membutuhkan waktu yang lebih dikarenakan kendala pada program yang tidak dapat mengelola database secara efisien.

Penggunaan program yang tepat sangatlah membantu untuk mengelola data barang yang tersedia di koperasi. Jika pengelolaan database tidak dilakukan secara efisien maka akan memperlambat proses informasi data barang yang diinginkan. Sehingga, dibutuhkan suatu program pendataan barang yang mampu menyimpan dan mengakses database secara rapi dan juga mampu menyediakan informasi dari barang koperasi yang diinginkan secara cepat dan akurat.

Koperasi SMP Negeri 23 Semarang merupakan koperasi sekolah yang meyediakan berbagai kebutuhan siswa maupun guru. Dengan kebutuhan barang sebanyak itu, staf koperasi mengalami permasalahan dalam mencari dan penginputan informasi data barang secara cepat. Berdasarkan observasi dan permasalahan yang penulis temui pada SMP Negeri 23 Semarang tersebut, maka penulis membangun sistem informasi pendataan stok barang yang dapat membantu staf koperasi untuk melakukan kegiatan pendataan barang secara cepat dan akurat.

Terminal barang merupakan sebuah nama untuk sistem pendataan barang di Koperasi SMP Negeri 23 Semarang. Sistem ini akan mempermudah staf koperasi untuk melakukan pekerjaannya. Mulai dari mengelola data keluarmasuk barang, transaksi pembelian, informasi jumlah barang, melaporkan data penjualan, pembelian serta profit penjualan. Sistem ini akan mempermudah staf koperasi untuk melakukan pekerjaan kesehariannya.

\section{LANDASAN TEORI}

\subsection{Pengertian Sistem}

Sistem terdiri dari sub-subsistem atau bagian-bagian sistem, yang terdiri dari subsistem- subsistem yang lebih kecil lagi atau modul-modul dan seterusnya sampai komponen terkecil. Sistem adalah sekelompok unsur yang erat hubungannya satu dengan yang lain, yang berfungsi bersamasama untuk mencapai tujuan tertentu (Sutabri, 2012).

\subsection{Pengertian Informasi}

Informasi menyebabkan pemakai melakukan suatu tindakan yang dapat ia lakukan atau tidak dapat dilakukan. Informasi adalah data yang telah diklasifikasikan atau diolah atau diinterpretasikan untuk digunakan dalam proses pengamblan keputusan (Sutabri, 2012).

\subsection{Pengertian Sistem Informasi}

Sistem informasi adalah suatu sistem di suatu organisasi yang mempertemukan kebutuhan pengolahan transaksi harian yang mendukung fungsi operasi organisasi yang bersifat manajerial dengan kegiatan strategi dari suatu organisasi untuk dapat menyediakan laporan-laporan yang diperlukan oleh pihak luar tertentu (Sutabri, 2012).

\subsection{Inventaris Aset}

Inventaris aset adalah serangkaian kegiatan untuk melakukan pendataan, pencatatan, pelaporan hasil pendataan asset, dan mendokumentasikannya, baik asset berwujud maupun asset tidak berwujud pada suatu waktu tertentu. Inventaris aset dilakukan untuk mendapatkan data seluruh aset yang dimiliki, dikuasai sebuah organisasi perusahaan (Khairullah, Soedijono, \& Fatta, 2017).

\subsection{Koperasi Sekolah}

Koperasi sekolah adalah koperasi yang didirikan dilingkungan sekolah yang anggota-anggotanya terdiri atas siswa sekolah. Koperasi sekolah didirikan dalam rangka menanamkan pendidikan koperasi kepada siswa agar tujuan pengembangan koperasi di Indonesia dapat terwujud (Nurbudiyani, 2013).

\subsection{Pengertian Website}

Website merupakan kumpulan dari halamanhalaman yang berhubungan dengan file-file lain yang saling terkait. Dalam sebuah website terdapat satu halaman yang dikenal dengan sebutan home-page. Homepage adalah sebuah halaman yang pertama kali dilihat ketika seseorang mengunjungi sebuah website (Nandari \& Sukadi, 2014). 
Pengembangan Rekayasa dan Teknologi, Vol 15, No. 2, Desember 2019, pp 71-75

p-ISSN: 1410-9840 \& e-ISSN: 2580-8850

http://journals.usm.ac.id/index.php/jprt/index

\subsection{Bootstrap}

Bootstrap merupakan sebuah framework CSS dari twitter, yang menyediakan kumpulan komponenkomponen antarmuka dasar pada web yang telah dirancang sedemikian rupa untuk digunakan bersama-sama. Selain komponen antarmuka, bootstrap juga menyediakan untuk membangun layout halaman dengan mudah dan rapi, serta memodifikasi pada tampilan dasar HTML untuk membuat seluruh halaman web yang dikembangkan senada dengan komponen lainnya (Bettaliyah, 2016).

\subsection{PHP (Hypertext Preprocessor)}

PHP merupakan bahasa berbentuk script yang ditempatkan didalam server baru kemudian diproses. Kemudian hasil pemrosesan dikirimkan kepada web browser klien. Bahasa pemrograman ini dirancang khusus untuk membentuk web dinamis. PHP (HyperText Preprocessor) merupakan bahasa utama script server-side yang disispkan pada HTML yang dijalankan di server, dan juga bisa digunakan untuk membuat aplikasi desktop (Sidik, 2014).

Metode yang digunakan dalam membangun Terminal Barang adalah metode prototyping, dimana nantinya sistem ini dapat dikembangkan lagi. Sistem pendataan barang koperasi dibangun dengan bahasa pemrograman PHP dan database yang digunakan adalah MySQL, sedangkan dalam penggambaran sistem secara umum menggunakan UML (Unified Modeling Language).

\subsection{MySQL}

Sistem basis data (DBMS) dapat diketahui dari cara kerja pengoptimasi-nya dalam melakukan proses perintah-perintah SQL yang dibuat oleh pengguna maupun program-program aplikasi yang memanfaatkannya.. MySQL adalah sebuah perangkat lunak sistem manajemen basis data SQL (Bahasa Inggris: database management system) atau DBMS yang multithread, multi-user dengan sekitar 6 juta instalasi di seluruh dunia (Ramadhani, Anis, \& Masruro, 2013) .

\subsection{Basis Data}

Bentuk basis data adalah sebuah aturan yang mengatasi masalah tersebut. Saat ini basis data memiliki peranan yang sangat penting dalam mengelola data yang ada di dalamnya. Basis data adalah kumpulan data yang saling berhubungan yang disimpan secara Bersama sedemikian rupa tanpa perulangan (redudansi) yang tidak perlu, untuk memenuhi berbagai kebutuhan (Fathansyah, 2012).

\subsection{XAMPP}

XAMPP adalah salah satu paket instalasi Apache, PHP, dan MySQL secara instan yang dapat digunakan untuk membantu proses instalasi ketiga produk tersebut sama seperti PHPTriad. XAMPP merupakan paket server web PHP dan database MySQL yang paling pouler dikalangan pengembang web dengan menggunakan PHP dan MySQL sebagai databasenya (Fathansyah, 2012).

\subsection{Metode Prototyping}

Metode Prototyping dalam pelakasnaannya, teknisi IT langsung berinteraksi dengan calon users dalam menganalisis, menunjukan model atau contoh aplikasi yang akan dibuat, dan seterusnya merupakan suatu proses iterasi (berlanjut dan berulang-ulang). Prototyping adalah metode pengembangan sistem informasi, yang pada pengerjaannya mencakup pula teknik merancang arsitektur sistem informasi dalam bentuk antarmuka grafis dan dalam taraf tertentu, hasil prototyping digunakan sebagai aplikasi siap pakai (Sulianta, 2017)

\section{ANALISA DAN PEMBAHASAN}

Fungsi Terminal Barang ini adalah semua data barang di Koperasi SMP Negeri 23 Semarang baik barang keluar maupun barang masuk dapat disimpan dan ditampilkan serta mempermudah dalam pengaksesan data barang di Koperasi SMP Negeri 23 Semarang. Terminal Barang ini digunakan oleh staf koperasi yang diperuntukan untuk mengolah data barang yang ada di Koperasi SMP Negeri 23 Semarang.

\subsection{Analisis Non Fungsional}

Analisis kebutuhan non fungsional dibutuhkan guna menghasilkan spesifikasi kebutuhan non fungsional. Spesifikasi kebutuhan non fungsional merupakan spesifikasi yang rinci tentang hal yang dilakukan sistem ketika diimplementasikan. Analisis ini diperlukan untuk menentukan output yang akan dihasilkan, input yang diperlukan, dan lingkup proses yang digunakan untuk mengolah input menjadi output.

\subsubsection{Analisis Pengguna}

Aplikasi ini digunakan oleh staf Koperasi SMP Negeri 23 Semarang untuk mengolah data barang koperasi. Tabel pengguna dapat dilihat pada Tabel 1. 
Pengembangan Rekayasa dan Teknologi, Vol 15, No. 2, Desember 2019, pp 71-75 p-ISSN: 1410-9840 \& e-ISSN: 2580-8850

http://journals.usm.ac.id/index.php/jprt/index

Tabel 1. Tabel Pengguna

\begin{tabular}{|c|c|c|c|c|c|c|}
\hline Pengguna & $\begin{array}{l}\text { Tanggun } \\
\text { g } \\
\text { Jawab }\end{array}$ & $\begin{array}{l}\text { Hak } \\
\text { Akse } \\
\text { s }\end{array}$ & $\begin{array}{l}\text { Tingkat } \\
\text { Pendidikan }\end{array}$ & $\begin{array}{l}\text { Tingkat } \\
\text { Keterampilan }\end{array}$ & $\begin{array}{l}\text { Pengalama } \\
\mathrm{n}\end{array}$ & $\begin{array}{l}\text { Jenis } \\
\text { Pelatiha } \\
\mathrm{n}\end{array}$ \\
\hline Koperasi & - & - & Minimal & Mengerti & - & - \\
\hline $\begin{array}{l}\text { SMP Negeri } 23 \\
\text { Semarang }\end{array}$ & & & SMA & penggunaan Web & & \\
\hline
\end{tabular}

\subsubsection{Use Case Diagram}

Perancangan Use Case Diagram Terminal Barang ditunjukan pada Gambar 1.

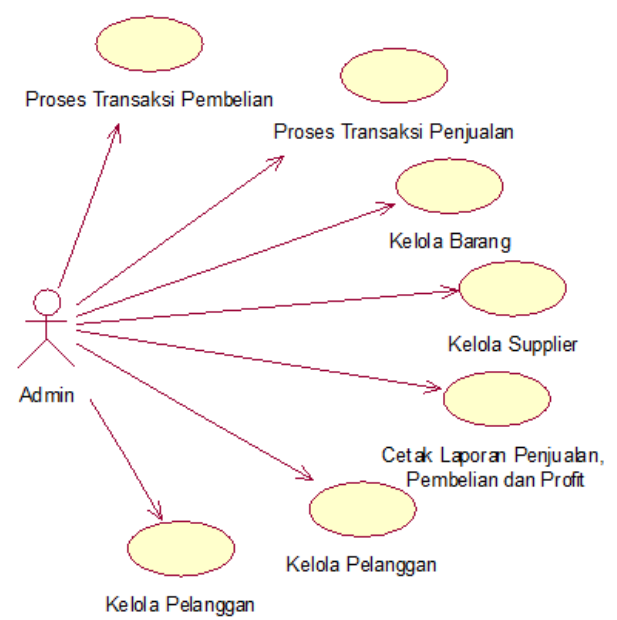

Gambar 1. Use Case Diagram Terminal Barang

\subsubsection{Class Diagram}

Perancangan Class diagram ditunjukan pada Gambar 2.

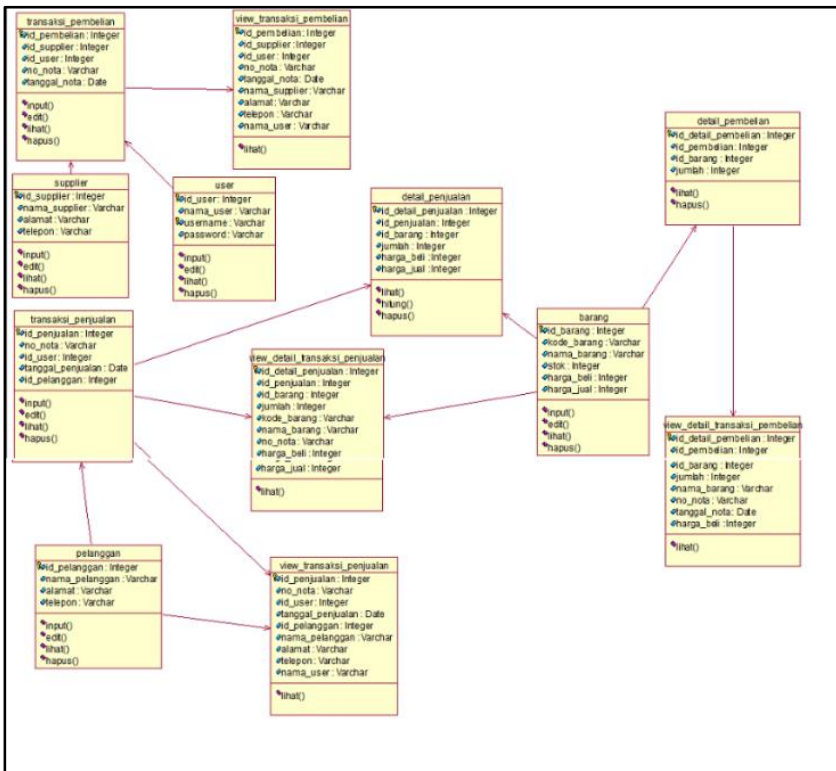

Gambar 2. Class Diagram Terminal Barang

\subsubsection{Sequence Diagram}

Perancangan sequence diagram pembelian ditunjukan pada Gambar 3.

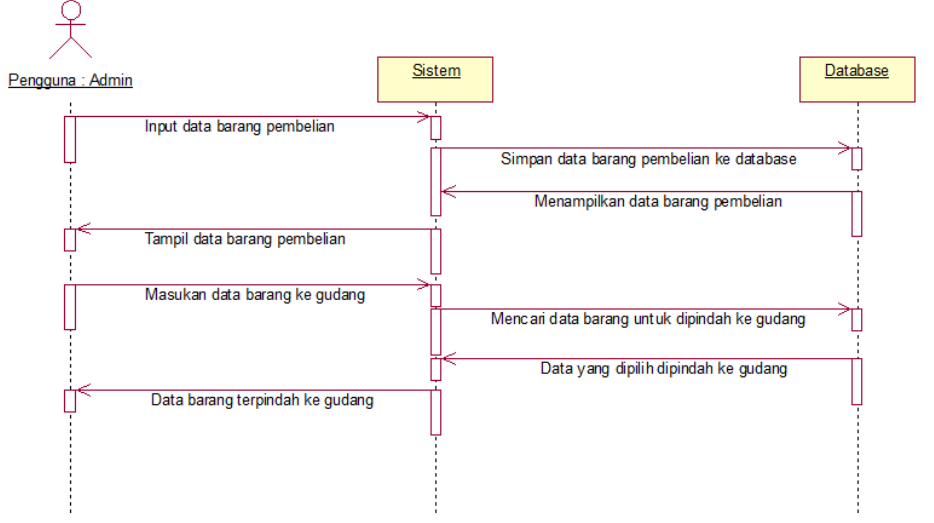

Gambar 3. Sequence Diagram pembelian Terminal Barang

\subsubsection{Sequence Diagram}

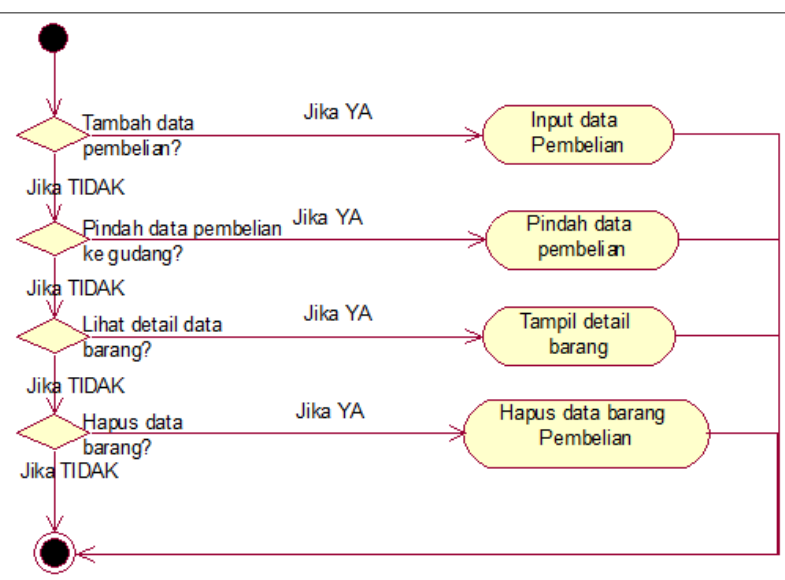

Gambar 4. Activity Diagram pembelian Terminal Barang

\subsection{Hasil}

Halaman utama ditunjukan pada Gambar 5. Halaman ini dapat diakses jika pengguna sudah berhasil login menggunakan username dan password yang sesuai. Halaman utama ini terdapat deskripsi singkat mengenai SMP Negeri 23 Semarang. Pada sisi kiri terdapat navigasi Home, Barang yang terdapat sub menu yaitu List Barang dan Tambah Barang, Supplier yang terdapat sub menu yaitu List Supplier dan Tambah Supplier, Pelanggan yang terdapat sub menu yaitu List Pelanggan dan Tambah Pelanggan, User yang terdapat sub menu yaitu List User dan Tambah 
Pengembangan Rekayasa dan Teknologi, Vol 15, No. 2, Desember 2019, pp 71-75

p-ISSN: 1410-9840 \& e-ISSN: 2580-8850

http://journals.usm.ac.id/index.php/jprt/index

User, Pembelian yang terdapat sub menu yaitu

List Pembelian dan Transaksi Pembelian, Penjualan yang terdapat sub menu yaitu List
Penjualan dan Transaksi Penjualan dan Laporan Profit.

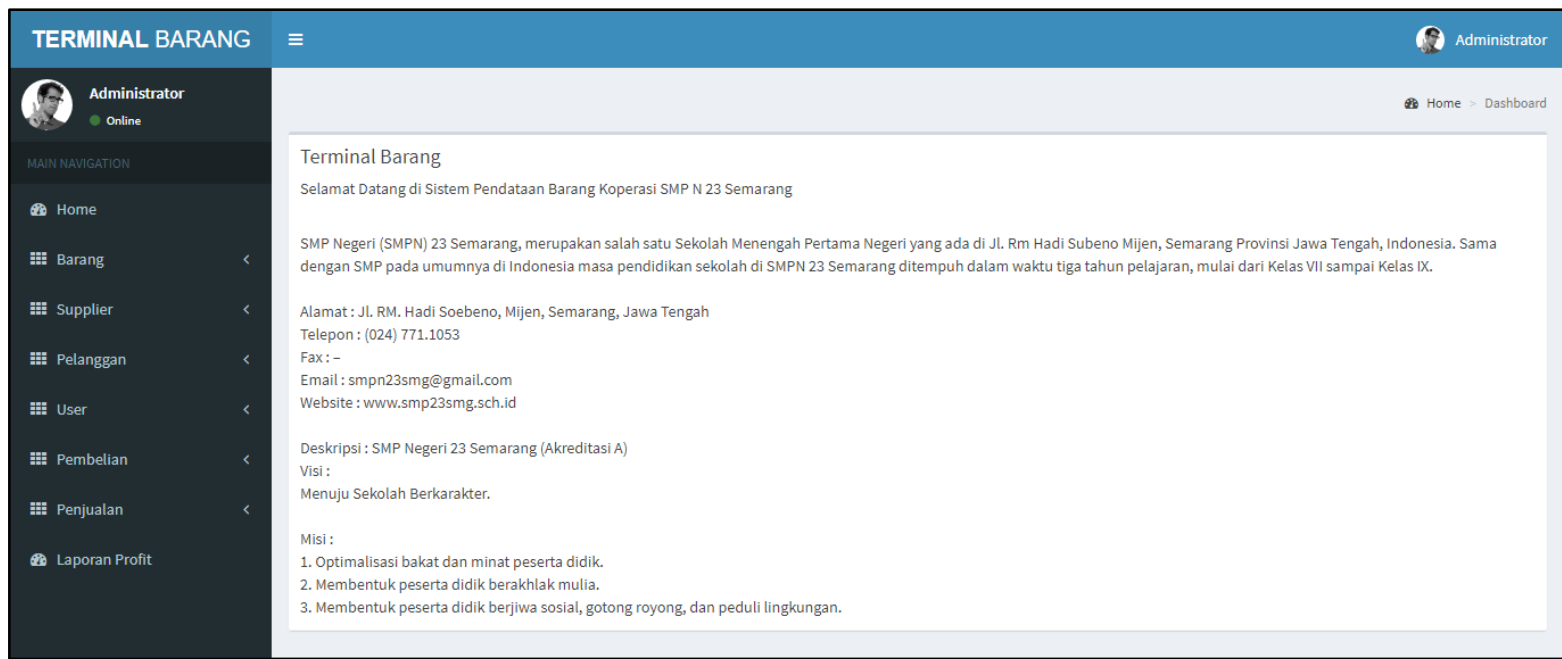

Gambar 5. Tampilan Halaman Utama

\section{KESIMPULAN}

Kesimpulan yang dapat diperoleh dari pembahasan sebelumnya mengenai Terminal Barang di Koperasi SMP Negeri 23 Semarang adalah Aplikasi Terminal Barang ini memudahkan staff koperasi dalam proses pendataan, pencarian dan pelaporan data barang koperasi, aplikasi ini juga dapat menyimpan, menampilkan dan melaporkan data barang serta transaksi di Koperasi SMP Negeri 23 Semarang secara cepat dan praktis, serta Terminal Barang menjadi aset SMP Negeri 23 Semarang dalam pendataan barang di Koperasi SMP Negeri 23 Semarang. Saran dari penelitian ini adalah sistem yang dibangun dapat dikembangkan lagi dengan penambahan fitur piutang untuk pendataan barang yang di hutang oleh pembeli dan dapat juga ditambahkan fitur metode pembayaran elektronik dan penambahan input pelanggan dalam jumlah besar dengan database yang terintegrasi.

\section{DAFTAR PUSTAKA}

[1] Bettaliyah, A. A. (2016). Sistem Informasi Pengolahan Data Tabungan Siswa MI Bahrul Ulum Berbasis WEB Mobile Menggunakan Codeigniter dan Bootstrap. Jurnal TeknikA, 841-849.

[2] Fathansyah. (2012). Basis Data. Bandung: Informatika.

[3] Khairullah, K., Soedijono, B., \& Fatta, H. A. (2017). Pengukuran Kualitas Sistem
Informasi Inventaris Aset Universitas Muhammadiyah Benguku Menggunakan Metode MCCALL. Jurnal Informasi Interaktif, 84-92.

[4] Munawar. (2018). Analisis Perancangan Sistem Berorientasi Objek dengan UML. Bandung: Informatika.

[5] Nandari, B. A., \& Sukadi, S. (2014). Pembuatan Website Portal Berita Desa Jetis Lor. IJNS - Indonesian Journal on Networking and Security, 43-47.

[6] Nurbudiyani, I. (2013). Model Pembelajaran Kewirausahaan Dengan Media Koperasi Sekolah di SMK Kelompok Bisnis dan Manajemen. Jurnal Pendidikan Vokasi,53-67.

[7] Ramadhani, S., Anis, U., \& Masruro, S. T. (2013). Rancang Bangun Sistem Informasi Geografis Layanan Kesehatan Di Kecamatan Lamongan Dengan PHP MySQL. Jurnal Teknika, 479-483.

[8] Sidik, B. (2014). Pemrograman WEB PHP. Bandung: Informatika.

[9] Sulianta, F. (2017). Teknik Perancangan Arsitektur Sistem Informasi. Yogyakarta: ANDI.

[10] Sutabri, T. (2012). Analisis Sistem Informasi. Yogyakarta: ANDI. 